\title{
The importance of personality in the context of human education: global experience and Vietnamese philosophical perspectives
}

\author{
Thi Thanh Quy Truong
}

DOI: 10.18355/XL.2019.12.04.17

\begin{abstract}
The human development in Vietnam after more than 30 years of renovation (Doi Moi) is not yet fully integrated into the global culture, failing to measure up to the standards of the developed nations within the UNO community. While some socio-cultural and economic indicators are now comparable to those of developed economies, the Vietnamese society experiences challenges in the area of holistic human development. Among the hindrances standing behind the slow pace of the Human Development Index in Vietnam today are degrading morality, feelings and experiences of estrangement (alienation), sub-optimal or even deviant values, declining faith (understood broadly), weak education, a lack of human approach in medicine, and cultural festivals boasting themselves as being "without culture." Reflecting on the necessity to face the grievous ethical and behavioral issues in the contemporary Vietnamese society, the author finds it necessary to study the human development orientation of a number of countries around the world in order to identify and then apply the learned lessons in the Vietnamese context. The article stresses the importance of personality and its development as one of the primary goals of human education.
\end{abstract}

Key words: principles of education, goals of education, Vietnamese development, philosophy of education, personality

\section{Introduction}

In the modern world, the human person and human society become an important target of social development, the core of socio-economic development strategies. Therefore, the development of each country is assessed not only on the basis of economic development, the GDP of each country or per-capita income of each country. The development of each nation is also assessed based on the Human Development Index (HDI) achieved by the given country. The Human Development Index is used by the United Nations to assess the development level of countries around the world, on a scale of 0 to 1 . Accordingly, the country with the higher HDI is up close to 1 , the people in that country have a higher standard of living. The human development index is assessed in three basic dimensions: GNI / person (The gross national income GNI per capita is calculated based on purchasing power parity conversion rates in US dollars); level of education attainment (the number of years of people's schooling); accessibility to quality health care (the lifespan of people).

In this article, the author approaches the human development from an educational and philosophical perspective. Education is here understood as crucial to the development of human capital, being one of the three key inputs (together with social capital and physical capital) that contribute to the economic development of each country. Therefore, countries are still looking not only for models and orientations for educational development but also for the kind of philosophy of education that would be most conducive to stated educational, social, and moral goals. How to develop education, what virtues and skills do various agents of the educational process need to concentrate on to help people behave and interact most effectively with their social environment, and to take responsibilities for the natural environment and the planet in general? Human education has a broad framework, including moral education, personality education, and quality education. Our study will explore the orientation 
and practice of some typical Asian and Western countries in the area of human education in the 21 st century, as well as outline general concepts and philosophical starting points in the human education in Vietnam. Based on this analysis, some suggestions are drawn for future educational and human development in Vietnam.

\section{Research Methods}

Studying the importance of personality in the context of human education as it is (and as it should be) implemented in Vietnam today while taking into account the global experience, requires an interdisciplinary scientific approach. Besides analyzing the social and educational environments in contemporary Vietnam, the author will reflect on relevant ethical and philosophical issues. The analysis will be complemented by comparison and synthesis in a dialectical way to facilitate for a comprehensive approach to the given research topic.

\section{The Realities of the Human Education Orientation in Selected Asian Countries}

The reason, we choose two Asian countries (Korea and Singapore) is because the achievements in education and economic development of these two countries are highly appreciated and desirable. Besides, due to Korea's and Singapore's geographic vicinity to Vietnam, their experience can bring useful insights and inspirations for Vietnam.

\section{South Korea}

Korea is a country with a highly developed education, which is one of the fundamental causes of the "Miracle on the Han River" admired by the whole world. Korea has a special geographical position with many similarities to Vietnam. It borders with the mainland of China from the East, while Vietnam borders with China from the South. Due to this geographical feature, both countries have many similarities both in history, culture as well as in understanding the nature of the human being. Both have been dominated by China in the past and have been strongly influenced by culture and religion from China, which is characterized by the introduction of Buddhism and Confucianism into the territories under its influence.

With the characteristics of a coherent and hierarchical society, Korea has attached special importance to human development, in order to develop the human capital for the economic development process, creating impressive results. Behind the rapid growth of Korea is the fact that the country has paid focused attention to education, especially building science and technology capabilities, achieving the goal of decreasing the technological gap with the leading Western countries and Japan. Korea strives and focuses on promoting the tripartite model in teaching students at all levels, beginning from kindergarten: (1) educational competency focused on cognition and intelligence, (2) physical competency and (3) ethical competency. In its education system, Korea also attaches great importance to creative experimental curriculum with two directions, encompassing both science and liberal education. The Korean personality development program comprises 20 values in four categories of life, including:

- (a) Each individual: respect the lives of others, honesty, sincerity, independence, and moderation

- (b) In the family, for the neighbors, in the school: every person needs to the filial piety and harmony; politeness, cooperation and education on the love of the school and the homeland.

- (c) For society: the human being needs to be educated and equipped with the spirit of law observance; care, protection and preserve of the environment; education on thinking and discretion; community awareness education.

XLinguae, Volume 12, Issue 4, October 2019, ISSN 1337-8384, eISSN 2453-711X 
- (d) For country and nation: Educate patriotism, love for the nation and humanity; educate the security awareness, peace and reunification (Roh 2004).

\begin{tabular}{|c|c|c|c|c|c|c|}
\hline \multicolumn{7}{|c|}{ Range of rank on the PISA 2006 science scale } \\
\hline & \multirow{2}{*}{$\begin{array}{l}\text { Mean } \\
\text { score }\end{array}$} & \multirow{2}{*}{$\begin{array}{l}\text { Standard } \\
\text { error }\end{array}$} & \multicolumn{2}{|c|}{ OECD countries } & \multicolumn{2}{|c|}{ All countries/economies } \\
\hline & & & Upper Rank & Lower Rank & Upper Rank & Lower Rank \\
\hline Finland & 563 & $(2.0)$ & 1 & 1 & 1 & 1 \\
\hline Hong Kong-China & 542 & $(2.5)$ & & & 2 & 2 \\
\hline Canada & 534 & $(2.0)$ & 2 & 3 & $\frac{6}{3}$ & 6 \\
\hline Chinese Taipei & 532 & $(3.6)$ & & & 3 & 8 \\
\hline Estonia & 531 & (2.5) & & & 3 & 8 \\
\hline Japan & 531 & (3.4) & 2 & 5 & $\frac{6}{3}$ & 9 \\
\hline New Zealand & 530 & $(2.7)$ & $\frac{2}{2}$ & 5 & $\frac{5}{3}$ & 9 \\
\hline Australia & 527 & (2.3) & 4 & 7 & 5 & 10 \\
\hline Netherlands & 525 & $(2.7)$ & 4 & 7 & 6 & 11 \\
\hline Liechtenstein & 522 & $(4.1)$ & & & 6 & 14 \\
\hline Korea & 522 & (3.4) & 5 & 9 & 7 & 13 \\
\hline Slovenia & 519 & (1.1) & 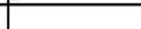 & & 10 & 13 \\
\hline Germany & 516 & $(3.8)$ & 7 & 13 & 10 & 19 \\
\hline United Kingdom & 515 & $(2.3)$ & 8 & 12 & 12 & 18 \\
\hline Czech Republic & 513 & $(3.5)$ & 8 & 14 & 12 & 20 \\
\hline Switzerland & 512 & (3.2) & 8 & 14 & 13 & 20 \\
\hline Macao-China & 511 & (1.1) & & & 15 & 20 \\
\hline Austria & 511 & (3.9) & 8 & 15 & 12 & 21 \\
\hline Belgium & 510 & $(2.5)$ & 9 & 14 & 14 & 20 \\
\hline Ireland & 508 & $(3.2)$ & 10 & 16 & 15 & 22 \\
\hline Hungary & 504 & $(2.7)$ & 13 & 17 & 19 & 23 \\
\hline Sweden & 503 & $(2.4)$ & 14 & 17 & 20 & 23 \\
\hline Poland & 498 & $(2.3)$ & 16 & 19 & 22 & 26 \\
\hline Denmark & 496 & $(3.1)$ & 16 & 21 & 22 & 28 \\
\hline France & 495 & $(3.4)$ & 16 & 21 & 22 & 29 \\
\hline Croatia & 493 & $(2.4)$ & & & 23 & 30 \\
\hline Iceland & 491 & (1.6) & 19 & 23 & 25 & 31 \\
\hline Latvia & 490 & $(3.0)$ & & & 25 & 34 \\
\hline United States & 489 & $(4.2)$ & 18 & 25 & 24 & 35 \\
\hline Slovak Republic & 488 & (2.6) & 20 & 25 & 26 & 34 \\
\hline Spain & 488 & (2.6) & 20 & 25 & 26 & 34 \\
\hline Lithuania & 488 & $(2.8)$ & & & 26 & 34 \\
\hline Norway & 487 & $(3.1)$ & 20 & 25 & 27 & 35 \\
\hline Luxembourg & 486 & $(1.1)$ & 22 & 25 & 30 & 34 \\
\hline Russian Federation & 479 & $(3.7)$ & & & 33 & 38 \\
\hline Italy & 475 & $(2.0)$ & 26 & 28 & 35 & 38 \\
\hline Portugal & 474 & $(3.0)$ & 26 & 28 & 35 & 38 \\
\hline Greece & 473 & $(3.2)$ & 26 & 28 & 35 & 38 \\
\hline Israel & 454 & $(3.7)$ & & & 39 & 39 \\
\hline Chile & 438 & $(4.3)$ & & & 40 & 42 \\
\hline Serbia & 436 & $(3.0)$ & & & 40 & 42 \\
\hline Bulgaria & 434 & $6.1)$ & & & 40 & 44 \\
\hline Uruguay & 428 & $(2.7)$ & & & 42 & 45 \\
\hline Turkey & 424 & $(3.8)$ & 29 & 29 & 43 & 47 \\
\hline Jordan & 422 & $(2.8)$ & & & 43 & 47 \\
\hline Thailand & 421 & $(2.1)$ & & & 44 & 47 \\
\hline Romania & 418 & $(4.2)$ & & & 44 & 48 \\
\hline Montenegro & 412 & $(1.1)$ & & & 47 & 49 \\
\hline Mexico & 410 & $(2.7)$ & 30 & 30 & 48 & 49 \\
\hline Indonesia & 393 & $(5.7)$ & & & 50 & 54 \\
\hline Argentina & 391 & $(6.1)$ & & & 50 & 55 \\
\hline Brazil & 390 & $(2.8)$ & & & 50 & 54 \\
\hline Colombia & 388 & (3.4) & & & 50 & 55 \\
\hline Tunisia & 386 & $(3.0)$ & & & 52 & 55 \\
\hline Azerbaijan & 382 & $(2.8)$ & & & 53 & 55 \\
\hline Qatar & 349 & $(0.9)$ & & & 56 & 56 \\
\hline Kyrgyzstan & 322 & $(2.9)$ & & & 57 & 57 \\
\hline
\end{tabular}

Statistically significantly above the OECD average

Not statistically significantly different from the OECD average

Statistically significantly below the OECD average

Table 1: Range of Rank on the PISA 2006 Science Scale 
Since 2006, Korea has made great efforts in pushing forth needed educational reforms and implemented new adjustments in its educational program. According to the most recent reform content of 2015, the modern school system in Korea consists of six years of elementary school, three years of junior high school and three years of high school (Vietnam Institute of Educational Sciences 2008:180-186). The students are required to attend elementary and middle school without paying for any educational expenses, except for a small fee called the "School Activity Support Fee". This fee varies in each school. According to the international student assessment program initiated and directed by the Organization for Economic Cooperation and Development (OECD) - Korea' scientific education has currently been ranked third in the world and it is higher that the OECD's average level (VNExpress 2018).

Although there are many achievements that can legitimately be admired, education in Korea also has some challenging issues to cope with, such as school violence, and fierce competition for getting the best grades in schools. In particular, after the sinking of Sewol ferry in April 2014, which killed 304 people, mainly 11th graders, there emerged a strong criticism within Korean society claiming that this crisis showed an acute disrespect for life and a serious lack of humanity and morality. Therefore, Korea adopted a new Act on Education - the Character Education Promotion Act No. 13004, 14396 and 15233 which came into effect in July 2015 with amendments in 2016 and 2017), focusing on the lessons of "psychology development and necessary attitude to live together with others and in harmony with nature", as well as on the core ethical values: politeness, filial piety, honesty, responsibility, respect, caring, communication and cooperation (Korea Law Translation Center 2019).

According to the content of the most recent reform in 2015, the ideology and educational goals were encapsulated in the concept of Hongik Ingan (the founding spirit of the first dynasty in Korean history). Accordingly, the goal of education in Korea is to support all people to improve their individual personalities and to develop their competency in order to achieve independent living and to attain a high level of citizens' democratic awareness, which could participate in building a democratic state and promote the prosperity of humankind. The "smart" education strategy in Korea aimed to improve competitiveness, raising the quality of education in Korea to match the top 10 countries with the most advanced education systems in the world by 2015 and the top three in the world by 2025. Korea's 2015 educational reforms upheld the goal of personality education, including:

- An independent person who can create his own identity and serve his future life, based on comprehensive growth and development;

- Distinct individual can create new things through the application of ideas and implement them in a spirit of resilience, based on the basic knowledge and skills;

- A delicate person shall have respect for the development of human culture, based on cultural competency and pluralistic values;

- A democratic citizen can interact with the world with a sense of community and know how to live with others in the same spirit of care and sharing (Theo 2012).

In order to achieve these goals, the education reform in Korea has identified the core skills needed to be developed by primary and secondary education, including:

- (1) Self-management competency: the ability to self-guide life brings its own identity and confidence, with the basic competencies needed in life and career.

- (2) Knowledge/ information ownership competency: the ability to gain knowledge and information from diverse resources to solve in a rational direction;

- (3) Creative thinking competency: the ability to create new things based on the integration of knowledge, skills and experience from various professional fields;

- (4) Aesthetic-emotional competency: the ability to discover and evaluate meaning and value of life based on empathy towards others and cultural sensitivity;

XLinguae, Volume 12, Issue 4, October 2019, ISSN 1337-8384, eISSN 2453-711X 
- (5) Communication competency: the ability to effectively express thoughts and emotions in different situations, to listen attentively and respect the opinions of others;

- (6) Civil competency: the ability to actively participate in ongoing community development activities, possessing the values and attitudes required to become a closely integrated member of the local, national and global community. (Theo 2012)

To adapt to the rapid changes in the world, especially in technology, South Korea makes great efforts to build a learning society (or 'knowledge-based' society), giving prominence to the role of education with the new emphasis on character formation. To help in this effort, Korea promulgated the Lifelong Education Act (1999), highlighting the four pillars as a lifelong learning platform: (1) Learning to know, (2) Learning to do, (3) Learning to live together and (4) Learning to be. In the fourth National Lifelong Learning Promotion Plan (2018-2022), in the context of what we have now come to call Industry 4.0, human creativity and integrated competency are the core components, conducive to growth motivation and technological innovation. In addition, lifelong learning also appears to be the most effective welfare policy to minimize social stratification with its detrimental (and ever-increasing) gap between the rich and the poor. Lifelong learning is considered an effective circulating triangle between the three pillars of "Growth - Employment - Welfare" that the Korean government is aiming at. The government's determination to create equitable educational opportunities and provide high-quality services is in line with Korea's fundamental welfare policies to minimize the existing social and economic inequalities.

\section{Singapore}

Singapore is a young nation in East Asia. Its history started being written after Singapore had been separated from the Federation of Malaysia in 1965. This former British colony has since become a trading gateway of the region with high growth and rising living standards. The island nation of Singapore is characterized by a multiethnic, multi-cultural and multi-religious society. The Singaporean population is very diverse with many ethnic groups including: the Chinese with $77 \%$, the Malaysians with $14 \%$, the Indians with $8 \%$, and the remaining $1 \%$ are the immigrants from other origins. It is also a country with a large number of foreign immigrant workers. According to the Singaporean Government's forecast, the immigrants will account for $50 \%$ of Singapore's population by 2030 .

As a small island nation, Singapore always faces numerous challenges, such as lack of natural resources, food safety issues, geopolitical considerations, etc. Confronted with these challenges, the Singaporean government decided to invest in its people by giving them the best possible education. In fact, Singapore's education is considered a "top national policy." On May 17, 1997, Deputy Prime Minister Lee Hsien Loong officially launched the National Education Program to enhance national unity and inspire the national identity among the students and young Singaporeans. The National Education Program emphasizes the island nation's core values of meritocracy, ethnic and religious harmony, and inventiveness.

Since the 1990s, Singapore has been one of the leading countries globally in building "the core competencies of the 21 st century" (the so-called '21CC') and in implementing educational reforms aimed at the "teaching less, learning more" principle to increase the proactivity of the students (Salas-Pilco 2013). Singapore's Ministry of Education 2009 Education Reform Program outlines four target outcomes for students including:

- Independent and confident individuals: To have a strong sense of right and wrong aspects, adaptation and persistence, be insightful in assessment, independent thinking and criticism, effective communication; 
- Self-reliant and self-directed individuals: To take responsibility for their own learning, know how to ask questions, reflect and persist in pursuing their learning;

- To become an active contributor: to work effectively in a team or group, implement their ideas, calculate risks, create and strive for their achievements;

- To educate individuals to become dedicated citizens: to connect with Singapore, have a strong citizen awareness and take an active role to improve the better surrounding life.

As far as human personality education is concerned, the island nation's educational program focuses on five ranges (Roh 2004) including:

- To build personality: to promote the strength of personality and interpersonal skills;

- Family relations: to respect family life;

- Community spirit: to promote the sense of belongings and caring for the community;

- Our country, our heritage: to increase our commitment to building our country and increasing our ability to appreciate our culture and religion;

- Challenges ahead: to raise awareness about the future challenges that the country faces with and which may undermine the people's beliefs in their country.

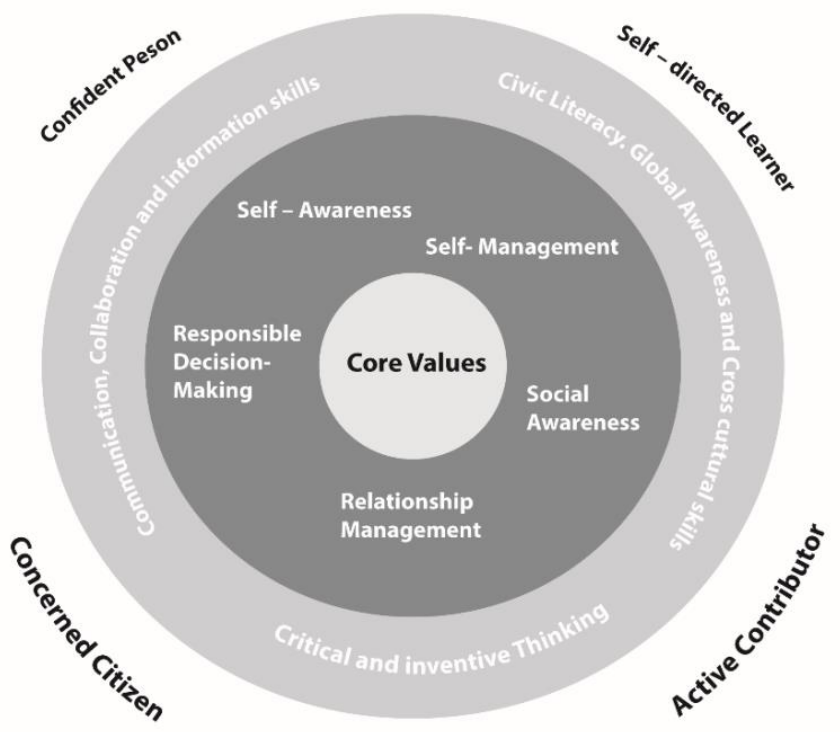

\section{Figure 1: Five ranges of human personality education (Roh 2004)}

Following the educational reform goals of 2009 , the Framework for the $21^{\text {st }}$ Century Competencies and the students' results have been also introduced by the island nation for the year 2010 and have continued to grow in the recent years. This framework has three layers: the first layer consists of 6 central core values of the Singaporeans (Respect, responsibility, resilience, integrity, care, harmony); the second layer is 5 social emotional capacities (Self-awareness, Self-Management, Social Awareness, relationship management, and responsible decision-making); The third outer layer is 
the emerging core competencies in the $21^{\text {st }}$ century that respond to the rapidly changing world, including: (1) civil capacity, global awareness and inter-cultural skills; (2)Critical and creative thinking; (3) Communication and information skills; Outmost are the last 4 goals for each Singaporean student including the cultivation of a confident and independent individual, who is a self-reliant learner, dedicated citizen and active contributor.

In order to educate the generation of citizens, form new personalities, and equip them with new competencies, the island nation attaches great importance to the teachers. This pertains closely to having an appropriate teaching model. In 2012, the Singapore promulgated a Teachers' Professional Development Model to encourage the teachers to study lifelong and have a prosperous, stable personal life (Hairon - Dimmock 2012). Thanks to effective and positive policies, these leading reforms have brought Singapore a high-ranking position in education, ICT readiness, healthy business environment, and recognition within the global innovation index (to mention but a few successes).

\section{Education Principles and Goals in Selected Western Countries}

Due to the different geographical, natural and cultural characteristics, especially the strong influence of the enlightenment culture and Judeo-Christian heritage, education in the Western countries has different emphases from the Asian countries. To illustrate this point, we have chosen two outstanding representatives from the West, the United States and France. France is known as the cradle of the modern European Culture, liberal thought and the revolution. The United States is a country that has significantly developed the quintessence of liberal thought, bringing it to a new level. The socio-cultural environment of the US has thus become a breeding ground for the emergence of new values and corresponding political, cultural and educational procedures that were no longer bound by the cultural traditions and class stratification of the European countries (Valco, 2018).

\section{The United States of America}

The human education's foundation in the United States comes largely from the British and the European continental education systems (mainly German). However, this rich heritage was adapted and developed by influential scholars and politicians on the American continent, such as Benjamin Franklin (1706-1790), Horace Mann (17961859) and William McGuffey (1800-1873) (Watz, 2011). As a president who laid the foundation for the United States, Franklin had a great influence on many areas of American life. In terms of education, he was a pioneer to promote the development of higher education institutions, fostering a consistent education system that paid special attention to moral education in public schools. Mann was the most influential scholar in personality development of the early American education with a focus on the physical, psychological and spiritual development of young Americans. He emphasized the principles of morality, fairness and longing for truth, patriotism, mercy and tolerance, alertness, industry, frugality, purity, moderation and modesty and virtues needed to beautify society and the inner character of the people (Downs, 1974). McGuffey, on the other hand, used the historical materials from poetry, speeches, and stories to help students imagine the desirable ethical principles and values in practice and outline human connections with the physical world. In McGuffey's views, appropriate literary materials can encourage children to have a spirit of hard work, self-discipline, kindness, perseverance (Berger, 2000). It is these great men who have laid the foundations for the development of education in the United States.

The early educational programs consisted primarily of activities organized by churches and social associations, such as Young Men's Christian Association (YMCA) and Boy Scouts of America (BSA). In particular, the YMCA created holistic 
programs that simultaneously develop the spiritual, mental and physical dimensions of the human person. In a similar fashion, BSA promotes the so-called 12 Scout laws with the goal of building a personality of trustworthiness, loyalty, kindness, friendliness, politeness, obedience, fun, thriftiness, courageousness, cleanliness and veneration, vowing to take responsibility before God and the country and comply with the Scout Law to help others at all times and to keep the person strong in one's physical constitution, alert in one's mental capacities, and frank in morality (Macleod, 1983; Watz, 2011). These programs, however, though naturally focused on developing basic knowledge and skills (like literacy) are also specifically focused on developing moral and religious education. This may create a gap between real life needs and challenges on the one hand and the set educational priorities on the other. Therefore, the situation of a more secularized and scientifically/technologically advanced society has required educational programs that would be more universal and applicable (Nguyen, 2012).

The United States is characterized by its liberal approach to educational requirements, that is, by not imposing a general education program nationwide. Each state within the US determines their own appropriate programs for their territory. Therefore, the popular personality education programs such as Heartwood Program, CharacterCount, Center for $4^{\text {th }}$ and $5^{\text {th }}$ Rs were developed on a state rather than national level. Specifically, the Heartwood program focuses on seven basic universal virtues: Courage, Loyalty, Justice, Respect, Hope, Honesty, and Love (Carnegie Mellon University 2018). Meanwhile, the CharacterCount program offers 6 personality pillars including: Trustworthiness, Respect, Responsibility, Fairness, Caring, and Citizenship (Marden Lodge 2018). The Center for the $4^{\text {th }}$ and $5^{\text {th }} \mathrm{Rs}$ is generally available in schools. Mr. Lickona, the Program Manager, presents 10 basic characteristics included in the Program: (1) Wisdom; (2) Justice; (3) Fortitude; (4) Self-control; (5) Love; (6) Positive attitude; (7) Hard work; (8) Integrity; (9) Gratitude; (10) Humility (Lickona 2003:2-3).

The United States does not have a unified educational program with the goal to develop the pupils' civic personality, morality, and sense of responsibility, and it lacks a generally accepted key framework of students' skills. This appears to be an ambivalent situation. On the one hand, the liberalized education market provides creative space for many actors to develop innovative approaches to education; on the other hand, it is difficult to oversee and manage the desirable educational outcomes to match any national criteria. To develop a generally accepted framework, the Federal government has proposed the Common Core State Standards Initiative that requires learners to be prepared with the required skills and knowledge to collaborate and compete with others inside and outside the United States. To meet the standard of skills and expertise, the US government also offers a series of common assessment certificates such as GRE and SAT or career certificates in each field to provide the needed assessment of students when they enter in the labor market or a university. The United States is also the initiator of the key competencies framework building programs required for the $21^{\text {st }}$ century. The most prominent is the framework of Partnership for $21^{\text {st }}$ Century Skills (also known as P21) used widely in building the skills required for students, and workers in general. Under this framework, from children at the kindergarten level to $12^{\text {th }}$ graders, the pupils need to master 9 main subjects, explore 5 interdisciplinary contents and develop three kinds of skills to prepare themselves for their careers and life successes. 


\begin{tabular}{|c|c|c|}
\hline $\begin{array}{l}\text { Information and } \\
\text { communication } \\
\text { technology competence }\end{array}$ & $\begin{array}{l}\text { Learning and } \\
\text { creative skills }\end{array}$ & Life and career skills \\
\hline $\begin{array}{l}\text { Information competence } \\
\text { Communication } \\
\text { competence } \\
\text { ICT competence }\end{array}$ & $\begin{array}{l}\text { Innovation and } \\
\text { Creation } \\
\text { Critical thinking } \\
\text { and problem solving } \\
\text { Communication } \\
\text { Cooperation }\end{array}$ & $\begin{array}{l}\text { Flexibility and adaptability } \\
\text { Innovation and self-direction } \\
\text { Social and intercultural skills } \\
\text { Productivity and } \\
\text { accountability } \\
\text { Leadership and responsibility } \\
\text { skill }\end{array}$ \\
\hline
\end{tabular}

\section{Table 2: Framework of Partnerships for the $21^{\text {st }}$ century skills}

The United States National Research Council, meanwhile, defines the framework for deep learning in the $21^{\text {st }}$ century that includes three areas of skills - cognitive, personal, and interpersonal - with the goals of deep learning and lifelong learning. The areas and skills are listed in the following Table:

\begin{tabular}{|l|l|l|}
\hline Cognitive scope & Personal scope & Interpersonal scope \\
\hline Critical thinking & studiousness & Communication \\
Information & Work ethics & Co-operation \\
competency & Dedication & Responsibility \\
Arguments and & Ability to self-assess & Conflict resolution \\
disputation & positive aspects & \\
Creation & & \\
\hline
\end{tabular}

Table 3: Framework of Deep Learning and the $21^{\text {st }}$ Skills of The United States National Research Council

P21 is by far the most popular and widely applied educational program, not only in the United States but also in many countries around the world.

\section{France}

France is considered the cradle of modern liberal thought and revolutionary ideas. France is also a land of highly sophisticated culture, which finds its expression in many aspects from the arts to ordinary human life. France is one of the European centers of literature and art with exquisite cuisine, architecture and fashion all of which are quintessential to the world of human culture. France's fundamental values are shown by the three stripes on its national flag that symbolize the three basic democratic principles: freedom, equality, brotherhood/charity (liberte, egalite, fraternite) and secularism (the so-called laicite).

The goal of every French is to preserve the republic with the ideal of "freedom, equality and charity". Other human values then stem from these three foundational principles/values. Accordingly, freedom means respect for oneself and the freedom of others; justice is the elimination of discrimination and respect for differences; charity emphasizes the role of unity, togetherness and solidarity. These three core values are reflected in three goals of personality education: (1) democratic virtues and republic; (2) individual and collective responsibility; (3) critical thinking and reasoning practiced through conversations and debates.

The core competencies affected by education for building in France have the application of European framework standards. The core competency for lifelong learning was laid out by the European Commission in 2018, with 8 components, including (European Commission 2018):

Basic competency: skills of mother language to be able to communicate and express personal views; 
- Linguistic competency: developing not only the mother language but also the foreign language in order to communicate across borders and flexibly use in Europe as well as in the globalized economy;

- Scientific, technological, technical and mathematical competencies: focusing on critical and problem-solving skills, which is a prerequisite for promoting technological progress and social development as well as mastering knowledge-based economy.

- Digital competency: focusing on 5 fields: (i) information and data competency including digital content management; (ii) communication, collaboration and social participation; (iii) creation of digital content including ethical principles; (iv) safety; (v) solution of problems. This competency is associated with social networks and the emergence of new technologies such as artificial intelligence (AI), robots, and virtual reality.

- Personal, social, and learning competencies: including three aspects: individual - self-awareness, physical and psychological health; society involving interpersonal interactions and working with others; and learning focusing on lifelong learning strategies and management skills in career development. In addition, the EU Competency Framework 2006 emphasizes creative virtues, critical thinking, problem solution, decision-making, selfdiscipline, etc. and new skills such as perseverance and ability to cope with uncertainties and complex situations;

- Civil competency: including active citizenship, participation, engagement and building of sustainable future, especially emphasizing the role of civic duty, democratic values and human rights in global society increasingly connected at the present. Understanding the needs, supporting sustainable societies, economies and ecosystems as well as practicing sustainable lifestyles as a key element of this competency;

- Leadership ability, entrepreneurship: considering creativity and planning ability and process management as the basic aspects of leadership thinking;

- Cultural awareness and expressive competency: understanding the forms of cultural expression and considering this as the key element to understand, develop and express the ideas, positions and roles in the society. In other words, it is the ability to recognize and shape the world from a sense of individual identity in relation to other individuals. A positive and open attitude for other cultures and cultural differences is also emphasized.

From the necessary 8 modules that comprise the EU core competencies for lifelong learning, France offers 7 core competencies, including: (1) the ability to use French fluently; (2) the ability to use foreign languages; (3) basic competency in math, science and technology; (4) the ability to fluently use common technologies in ICT; (5) compassionate culture; (6) social and civil competencies; (7) autonomy and initiative in making initiatives. Thus, the French version exhibits a certain variation, replacing the cultivation of leadership skills by fostering initiative. Or, as Gordon rightly points out, "It can be noted that the 'French' version of the competences transforms 'sense of initiative and entrepreneurship' into simply 'sense of initiative', to prevent ideological clashes, and raises humanistic culture to the rank of the major competences, while the European framework speaks only of "cultural awareness and expression." (Gordon et al. 2012: 90).

\section{Orientation of Human Education for the $21^{\text {st }}$ Century}

As mentioned above, the most popular human education framework in the $21^{\text {st }}$ century is P21. P21's student goals and comprehensive support system are shown in the figure below (The Partnership for $21^{\text {st }}$ Century Skills 2009). 


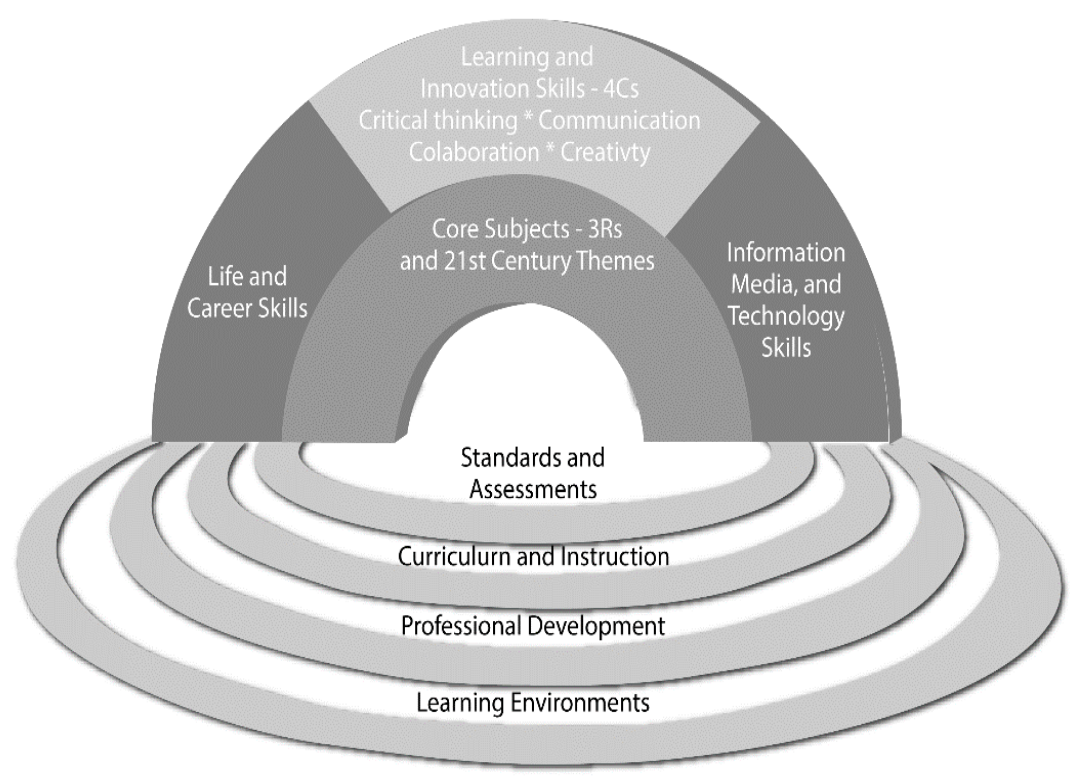

Figure 2: Goal framework and support system for $21^{\text {st }}$ century students (P21)

In particular, the topics of the $21^{\text {st }}$ century include: (1) global awareness; (2) financial, economic, business competencies and entrepreneurship; (3) Civil competency; (4) health competency; (5) Environmental competency. In addition, there are three basic competencies in information, communication and ICT. The necessary life and career skills are flexibility and adaptability, initiative and self-direction, society and interculturality, productivity and accountability, leadership and responsibility. There are 4 learning and creative skills (the so-called 4C's): critical thinking and problem solution, communication, collaboration, innovation and creativity.

The OECD (2016) gives necessary skills competencies directed towards 2030 in three competencies: 


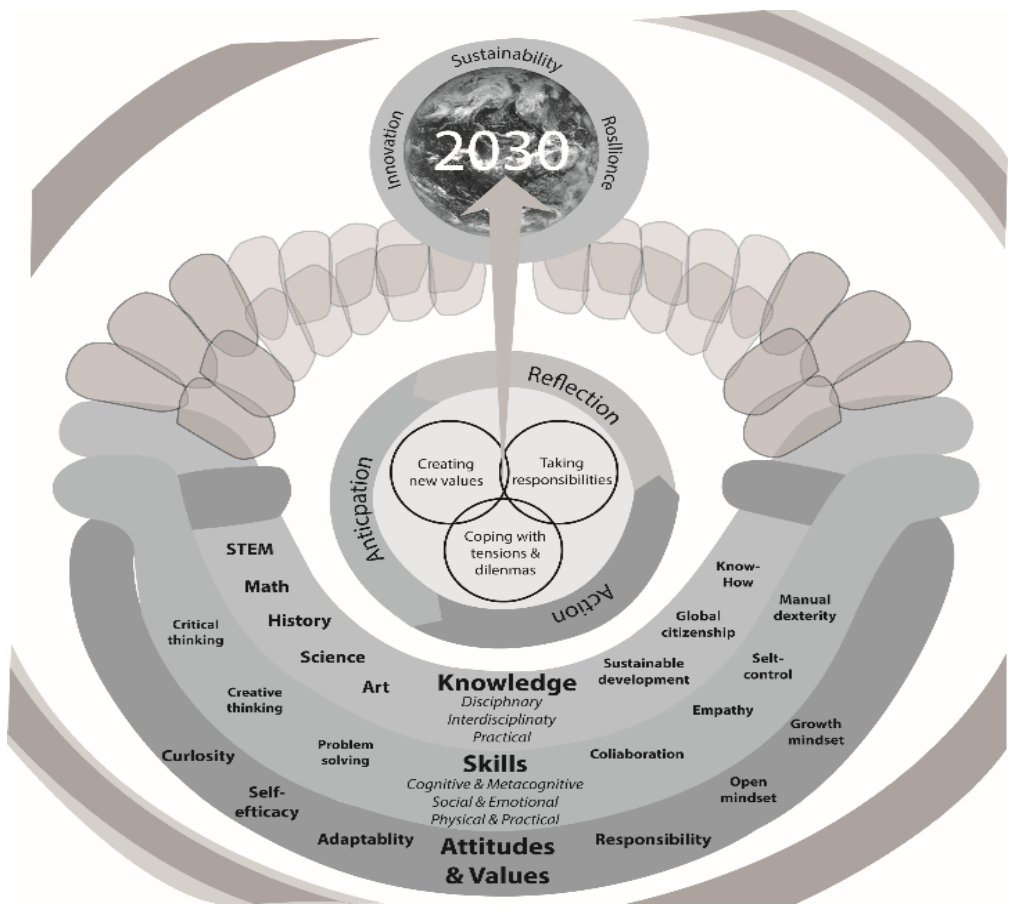

Figure 3: Three key competencies according to the OECD (2016)

(1) Knowledge (in relation to field of study, interdisciplinary and practice): STEM, math, history, science and art along with sustainable development, civic responsibility, the global, know-how.

(2) Skills (in relation to awareness and multi-awareness, society and emotion, physical and practice): critical thinking, creative thinking, problem solution, collaboration, empathy, discipline and finesse.

(3) Attitude and values: inquisitive, effective, adaptive, responsible, open-minded and growth-mindset.

These three areas will likely produce new values directed at cultivating one's personal sense of responsibility and the ability to respond constructively to conflicts and difficult situations. The ultimate goal is Sustainability - Perseverance - Creativeness.

Recent theoretical research as well as the numerous applications of theoretical models in countries around the world elevate the following 9 basic skills that appear to be indispensable in the $21^{\text {st }}$ century: critical thinking, creativeness, metacognition (or multi-awareness), problem solution, collaboration, motivation, efficiency, dedication, and perseverance (Lamb et al. 2017). Particularly important for the OECD countries are also skills oriented towards software competence, the ability to work in collaboration with others, and communication in a multicultural environment. Therefore, the skills to respect differences, sympathy, tolerance and multicultural awareness have a permanent place in the curriculum from kindergarten to $12^{\text {th }}$ grade. These educational frameworks emphasize the development of three areas of competencies: (1) basic competencies in literacy, science and technology, information, ICT, etc.; (2) lifelong learning and creative competencies; (3) and the competencies for life and career. 


\section{Suggestions Relevant for the Human Education in Vietnam}

Practical issues of human education and development in Vietnam

Vietnam currently belongs to the group of countries with an upper-middle level of HDI, more specifically 0.694 points which places Vietnam on the $116^{\text {th }}$ position out of 189 countries worldwide. The average life expectancy in Vietnam is 76.5 years. Vietnam belongs among the top 16 countries with the highest percentage of Internet usage with over 60 million social network users in 2018 (May 2018). ${ }^{1}$

\section{Vietnamese Human Development Index and its Components 1995-2018}

\begin{tabular}{|c|c|c|c|c|c|c|c|c|c|}
\hline \multicolumn{10}{|c|}{$\begin{array}{l}\text { Vietnamese Human Development Index and its Components 1995-2009 } \\
\text { (Source: UNDP Human Development Report, Table1 HDR 1995-2014). }\end{array}$} \\
\hline Years & 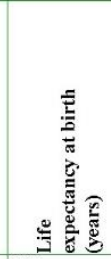 & 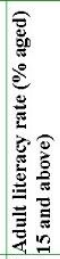 & 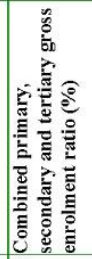 & 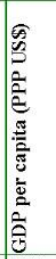 & 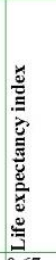 & 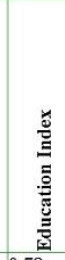 & $\begin{array}{l}\text { GDP } \\
\text { Index }\end{array}$ & $\begin{array}{l}\text { HDI } \\
\text { Value }\end{array}$ & $\begin{array}{l}\text { Rank } \\
\text { HDI }\end{array}$ \\
\hline 1995 & 65,2 & 91,9 & 49 & 1010 & 0,67 & 0,78 & 0,17 & 0,539 & $120 / 174$ \\
\hline 1996 & 65,5 & 92,5 & 51 & 1040 & 0,68 & 0,79 & 0,11 & 0,523 & $121 / 174$ \\
\hline 1997 & 66,0 & 0,93 & 55 & 1208 & 0,68 & 0,80 & 0,18 & 0,557 & $121 / 175$ \\
\hline 1998 & 66 & 93,7 & 55 & 1236 & 0,69 & 0,81 & 0,18 & 0,560 & $122 / 174$ \\
\hline 1999 & 67,4 & 91,9 & 62 & 1630 & 0,71 & 0,82 & 0,47 & 0,664 & $110 / 174$ \\
\hline 2000 & 67,8 & 92,9 & 63 & 1689 & 0,71 & 0,83 & 0,47 & 0,671 & $108 / 174$ \\
\hline 2001 & 67,8 & 93,1 & 67 & 1860 & 0,71 & 0,84 & 0,49 & 0,682 & $101 / 162$ \\
\hline 2002 & 68,2 & 93,4 & 67 & 1996 & 0,72 & 0,84 & 0,50 & 0,688 & $109 / 173$ \\
\hline 2003 & 68,6 & 92,7 & 64 & 2070 & 0,73 & 0,83 & 0,51 & 0,688 & $109 / 175$ \\
\hline 2004 & 69,0 & 90,3 & 64 & 2300 & 0,73 & 0,82 & 0,52 & 0,691 & $112 / 177$ \\
\hline 2005 & 70,5 & 90,3 & 64 & 2490 & 0,76 & 0,82 & 0,54 & 0,704 & $108 / 177$ \\
\hline 2006 & 70,8 & 90,3 & 63 & 2745 & 0.76 & 0,81 & 0,55 & 0,709 & $109 / 177$ \\
\hline $\begin{array}{l}2007 \& \\
2008\end{array}$ & 73,7 & 90,3 & 63,9 & 3071 & 0,812 & 0,815 & 0,572 & 0,733 & $105 / 177$ \\
\hline 2009 & 74,3 & 90,3 & 62,3 & 2600 & 0,821 & 0,810 & 0,544 & 0,725 & $116 / 182$ \\
\hline
\end{tabular}

Table 4: Vietnamese Human Development Index and its Components 1995-2009

\footnotetext{
${ }^{1}$ Vietnam has $60 \%$ of its population connected to the Internet - ranking $16^{\text {th }}$ in the world, with an average use of 7 hours a day. In total, 60 million Facebook users in Vietnam spend 3.55 hours on it a day. Additionally, YouTube has 45 million users each month in Vietnam with an average use of 2.65 hours a day. Zalo has 50 million users a month with an average use of 2.12 hours a day. By comparison, Google takes up $95.2 \%$ of the search market. (Mai 2018: https://thanhnien.vn/tai-chinh-kinh-doanh/60-trieu-nguoi-viet-su-dung-facebook-1031621.html)
} 


\begin{tabular}{|c|c|c|c|c|c|c|c|c|}
\hline Years & 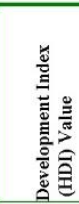 & 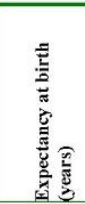 & 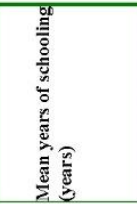 & 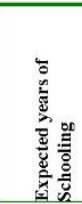 & 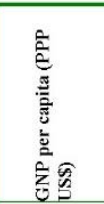 & 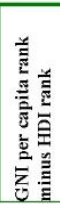 & 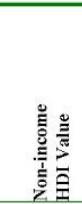 & $\begin{array}{l}\text { HDI } \\
\text { Rank }\end{array}$ \\
\hline 2010 & 0,572 & 74,9 & 5,5 & 10,4 & 2975 & $/ / 1$ & $\begin{array}{l}0,646 \\
0,572\end{array}$ & $113 / 178$ \\
\hline 2011 & 0,593 & 75,2 & 5,5 & 10,4 & 2,805 & 8 & 0,662 & $128 / 187$ \\
\hline 2013 & 0,617 & 75,4 & 5,5 & 11,9 & 2,970 & 9 & 0,686 & $127 / 188$ \\
\hline 2014 & 0,638 & $\begin{array}{l}75,9 \\
80,5 / 71,3 \\
\text { Woman/ } \\
\text { Man }\end{array}$ & $\begin{array}{l}5,5 \\
5,2 / 5,7 \text { Woman/ } \\
\text { Man }\end{array}$ & 11,9 & $\begin{array}{l}4,892 \\
4,174 / 5,655 \\
\text { Woman// } \\
\text { Man } \\
\end{array}$ & 0 & 0,653 & $121 / 187$ \\
\hline 2015 & 0,666 & 75,8 & 7,5 & 11,9 & 5,092 & 15 & $\ldots \ldots$ & $116 / 188$ \\
\hline 2016 & 0,683 & 75,9 & 8,0 & 12,6 & 5,335 & 18 & $\ldots \ldots$ & $115 / 188$ \\
\hline 2018 & 0,694 & 76,5 & 8,2 & 12,7 & 5,895 & 14 & $\ldots \ldots$ & $116 / 189$ \\
\hline
\end{tabular}

Table 5: Vietnamese Human Development Index and its Components 2010-2018 ${ }^{2}$

The challenge regarding how to nurture and educate people has always been a matter of concern on both the macro and the micro scale. However, the theory of "a new people" of the 1960s-80s, along with the more recent theory of "human development" that is still being developed today, continue to exhibit deficiencies as they underestimate the complexity of the issue, including the political and social institutions' and socio-economic mechanisms' role in shaping human's character, and moral development.

The problem is the institutions and the available mechanisms to shape human characters rarely reflect the subjective attitudes or opinions, whether those belong to government or scientists. The standards that guide the process of human development might seem perfect in theory, but in practice they often lead to unwanted consequences, especially in an economy transitioning from the central planned system to the global free market system (with necessary social mechanism to promote solidarity). Furthermore, there are no inclusive institutions within Vietnam's political system (Acemoglu - Robinson 2013).

Education and medicine were previously considered to be areas that could not tolerate any morally degraded persons. Recently, however, a situation of "crisis" developed in both these areas. In education, there are many problems pertaining to administration, management and even daily school activities that are difficult to solve. Scandals have occurred repeatedly and with a high frequency. For example, the scandal of school autonomy, or of several high schools and universities condoning immoral and illegal practices such as cheating during exams, school violence, moral degradation of schoolteachers, and sexual harassment. The Ministry of Education cannot handle all these scandals effectively, as they occur one after another. ${ }^{3}$ The situation is even more complicated by the fact that the "liberalization of Vietnam's economy has brought

\footnotetext{
${ }^{2}$ Since 2010, the Human Development Report (HDR) introduced several new measures of human development index, which it has since continued to estimate and report on annually. See: (United Nations Development Programme 2018: http://hdr.undp.org/en/countries/profiles/VNM) ${ }^{3}$ For example, the case of cheating by raising the grades of many students during high school exams in 2018 has become a national concern. Many officials in Ha Giang, Son La, and Hoa Binh are prosecuted in connection with this case. Pedophilia and sexual harassment have occurred more frequently in many provinces. In the first half of 2018, there were 682 cases of violation against 735 children and 572 cases of sexual violations with 562 children victims. Notably, 6,2\% children were victims of violations committed by the school staff, or teachers. (Anh 2018: http://csnd.vn/Home/Nghien-cuu-Trao-doi/4671/Van-nan-xam-hai-tinh-duc-hocduong)
} 
abrupt shifts in management and institutional oversight" (Do - Valco, 2018: 608). Even though education has always been a crucial matter on the national agenda, it seems that the crisis of education has not come to an end; on the contrary, Vietnam seems to be facing old and new challenges with a new urgency.

Given the situation of a deep crisis, the estrangement of Vietnamese people becomes harder to manage and to cope with constructively. In recent years, there have been too many severe cases that reflect the moral degradation and human estrangement in the society. Criminal offenses occur more frequently and become more grievous. Just for an illustration, there were more than 25,800 criminal offenses in the country, including 108 cases where the juveniles used weapons and caused serious damage, within the first 6 months of 2018 alone (TTXVN, 2018).

\section{Lessons from the New Focus on Human Education Relevant for Vietnam}

The purpose of human education is to lead the students to adopt the desired core values and to transform these into real-life competences and personal attitudes that would direct their thinking and behavior not only in a self-serving manner but also in a manner that promotes the rights of society and the interests of the nation and humanity. From the general characteristics of human development in Vietnam and the conflicting practical phenomena, we realize that Vietnam needs to analyze carefully and learn from the principles and best practices of foreign educational systems.

Based on the human education reforms and emphases of the four analyzed countries Korea, Singapore, the United States, and France - we can observe that they have focused on comprehensive education of students aimed at holistic development of their physical, ethical and soft skills. Although the contents of the respective educational programs and the specific emphases of each country exhibit some differences, these are not irreconcilable. We can legitimately summarize that the contents of human education reforms conducted in these countries in recent years have changed their focus to developing the core skills for the $21^{\text {st }}$ century. The formulation of the desired skills along with the appropriate mechanisms and environment conducive to their cultivation were motivated by the recognized need to help students to adapt, take advantage and bring new values and skills into the context of our changing, globalized world. Although the analyzed countries show a certain measure of preservation of their traditions, they appear to use and adapt their moral, social, and cultural heritage in an innovative, creative manner. They understand that the core skills and competencies that are instilled in the students today will be the key elements to determine the future success of their nation. Therefore, the humanoriented education is aimed at building a new generation of independent and responsible citizens who, while appreciating their national and cultural identity, and contributing to the wellbeing of their country, can also appreciate the values and emphases promoted by the international community and can adapt these creatively to the needs of their home environment.

In modern human education, personality formation and character development are given special attention by three of the four analyzed countries. In the case of the Korean educational system we can see four distinct areas where such focused attention is visible: individual development, family-neighbor-school, society, country and nation. Singapore has set four goals for human education (including independent and responsible individual, positive contributions and caring) with 5 core values in society: respect, responsibility, autonomy, integrity, care, harmony. France strives to educate its citizens to uphold the basic values of the republic reflected in the slogan "equality, freedom and charity". The United States, with its diverse characteristics and state-based system of curriculum development, does not impose a common value system or general education framework, yet it remains at the top of the global trends in building a viable competency framework for new generations of citizens. The 
federal system in the country only establishes quality verification bodies and a standardized evaluation system to check the output of human-oriented education.

The purpose, goals, and contents of education must always reflect the established and cherished human values in the given socio-cultural and political context (Smith 1968). Based on the experience of the analyzed countries, we argue that the common goal of human education is to be physically and mentally healthy; to adopt and personally develop all necessary life-competencies; and to develop the right attitudes and habits of active, pro-social participation in activities that lead to character development and enhancing one's life outcomes. Ethical education is also linked to cognitive, emotional, physical and social education of the human in his/her own historical context (Prokhorov - Chernov - Yusupov, 2017). Moreover, ethical education and character formation in the developed countries is flexible, creative, and innovative, using ethical stories, analyses of appropriate literary pieces or historical accounts, and especially emphasizing the need to instill desirable habits through practical training opportunities (i.e. role playing, field trips, problem solving situations, etc.) (Song Ustin - Popov - Mudarisov, 2017). The connection between theory and practical life must always be obvious, otherwise the motivational component of the educational process decreases significantly.

It is worth noting that the educational programs of many East Asian countries (in fact, especially East Asian countries) are being changed to reflect the trend of a studentcentered system. They understand the value of increasing the student's initiative and autonomy (primarily in terms of a developed sense of personal responsibility), increasing adaptability, moving towards a lifelong learning society, supporting the workers to improve their skills as well as to re-train the workers to adapt to a rapidly changing job market.

\section{Conclusion}

Our analysis of contemporary global trends in education, based on the selected four countries analyzed in this study, indicates that the Vietnamese educational system can draw inspiration from the treasure-trove of international experience. Though it is clear that solutions that work in other contexts, regardless of whether these are Western or East Asian contexts, will not necessarily work in the Vietnamese context, there are important lessons to be learned from those who have succeeded in their educational reforms and whose educational outcomes outperform the current Vietnamese outcomes by a wide margin.

Here we need to remind ourselves that for the purposes of this and any future analysis we must not focus solely on the direct outcomes of a given educational system (i.e. the levels of acquired knowledge, skills, etc.) but we must take into account the indirect outcomes as well, namely the scientific, technological, and economic competitiveness of the given country (Cai - Youngblood - Khodyreva Khuziakhmetov, 2017). This is namely closely related to the country's level of educational system. The level of corruption and overall crime rate seems also to be related to the nature and efficiency of the country's educational system, though more studies need to be conducted to prove and measure this relationship. Vietnam will need to rediscover its traditional values and recollect the foundational historical and national narratives $(\mathrm{Ho}, 2001)$ that are linked to those values. ${ }^{4}$ However, this process

\footnotetext{
${ }^{4}$ There are important roots of Vietnamese philosophical and political thinking going back 2000 years. One of the most prominent Vietnamese philosophers and politicians whose ideas are still being discussed today is surely Nguyen Trai (1380-1442). His political ideas and reflections on the nature and place of virtues in the life of an individual as well as that of the society are analyzed and interpreted by numerous contemporary thinkers striving to uncover and learn from
} 
must exhibit a good dose of flexibility and creativeness in order to adapt the treasure of the past for the challenges of the present (Do - Valco 2018). Increasing the level of internationalization at the Vietnamese universities, or even high schools, will likely help in this process. Student and teacher mobilities, international workshops and seminars, international summer schools and development projects have a good potential to create a fertile environment for the much-needed exchange of ideas and best practices.

Also important, though not so well analyzed in East Asian contexts, is the connection and cooperation between the school and the family. Family remains the most important formative environment for the emerging human agency - the morally and socially responsible human persons (mainly psychologically but in terms of the socialization of children in various human environments). A healthy, highly stimulating family environment is conducive not only to a healthy and robust character development but also to the cognitive and psycho-motoric readiness of the human individual to benefit from the educational process. Hence, we may infer that without a proper, well developed and focused policy that would promote the cooperation between schools (especially on the primary level) and parents, the results of any future educational reforms will likely be less than acceptable. However, (1) to scientifically assess the role of the family in the development of the child's readiness to socialize and study in schools and (2) to measure the direct impact that an active cooperation between the school and the family might have on the outcomes of the educational process, will require a separate study.

\section{Bibliographic references}

ACEMOGLU, D. - VA ROBINSON, A.J. 2013. Tai sao cac quoc gia that bai: nguon goc cua quyen luc, thinh vuong va ngheo doi [Why nations fail: the source of power, prosperity and poverty]. Ho Chi Minh City: Young Publisher.

ADB. 2019. Poverty in Vietnam. Available online: https://www.adb.org/countries/viet-nam/poverty.

ANH, T.H.A. 2018. Van nạn xam hại tinh dục học duong [Sexual harassment in school].. Available online: http://csnd.vn/Home/Nghien-cuu-Trao-doi/4671/Van-nanxam-hai-tinh-duc-hoc-duong

BBC. 2017. 12 dai an nham vao nhieu ngan hang [12 grand judges targeting many banks]. Available online: https://www.bbc.com/vietnamese/vietnam-39793579

BERGER, A. 2000. McGuffey's bicentennial: Reasons to remember. In: Education Today, vol. 18 , n. 2, p. 9 .

BUI, V. N. 1964. Discussing the Nguyen Trai's thought of humanity. In: Journal of Philosophy, vol. 60, n. 3, pp. 23-37.

CAI, J. - YOUNGBLOOD, V.T. - KHODYREVA, E.A. - KHUZIAKHMETOV, A.N. 2017. Higher Education Curricula Designing on the Basis of the Regional Labour Market Demands. In: EURASIA Journal of Mathematics, Science and Technology Education, vol. 13, n. 7, pp. 2805-2819. ISSN 13058215, 13058223.

CARNEGIE MELLON UNIVERSITY. 2018. Heartwood Ethics Curriculum for Children. Carnegie Mellon University Children's School. Pittsburg. Available online: http://character-education.info/Articles/TheContentofOurCharactor.pdf

DOAN, C. - BUI, T. B. 2015. Contributing to understanding Nguyen Trai's philosophical thought. Hanoi: National Political Publishing House.

DOWNS, R.B. 1974. Horace Mann: Champion of Public Schools. New York: Library of Congress.

Vietnam's ancient cultural traditions. See: (Bui, 1964; Doan - Bui, 2015; Le, 2016; Tran, 2002; etc.). 
EUROPEAN COMMISSION. 2018. Council Recommendation of 22 May 2018 on key competences for lifelong learning. Brussels. Available online: https://eurlex.europa.eu/legal-

content/EN/TXT/?uri=uriserv:OJ.C_.2018.189.01.0001.01.ENG\&toc=OJ:C:2018:189 :TOC

GORDON, J. - REY, O. - SIEWIOREK, A. - VIVITSOU, M. - SAARI, R. 2012. KeyCoNet 2012 Literature Review: Key competence development in school education in Europe. [Research Report] Key Competence Network on School Education. Available online: https://hal-ens-lyon.archives-ouvertes.fr/ensl01576387/document

HA, A. 2019. Du tru ngoai hoi Viet Nam dang o muc nao? [Vietnam's foreign exchange reserves are at a certain level]. EnterNews Portal. Available online: https://enternews.vn/du-tru-ngoai-hoi-viet-nam-dang-o-muc-nao-147866.html

HAIRON, S. - DIMMOCK, C. 2012. Singapore schools and professional learning communities: Teacher professional development and school leadership in an Asian hierarchical system. In: Educational Review, vol. 64, n. 4, pp.405-424.

HIEU, C. 2019. Chu dau tu ngoi chua lon nhat the gioi tai Ha Nam thu loi the nao? [How does the owner of the world's largest temple in Ha Nam profit?]. Available online: https://news.zing.vn/chu-dau-tu-ngoi-chua-lon-nhat-the-gioi-tai-ha-nam-thuloi-the-nao-post915263.html

HO, T. T. (ed.). 2001. The Country of Memory: Remaking the Past in Late Socialist Vietnam. Berkeley - Los Angeles - London: University of California Press.

KAWADA, H. - LEVINE, S.B. 2014. Human Resources in Japanese Industrial Development. Princeton, NJ: Princeton Legacy Library.

$\mathrm{KOH}$, A. 2011. Singapore's 'global assemblage': Digging into the culture of education policy making. In: Critical Studies in Education, vol. 52, n. 3, pp. 267-278.

KOREA LAW TRANSLATION CENTER. 2019. Character Education Promotion Act. Available online:

http://elaw.klri.re.kr/eng_mobile/viewer.do?hseq=46387\&type=part\&key=16

LAMB, S. - MAIRE, Q. - DOECKE, E. 2017. Key skills for the $21^{\text {st }}$ Century: an evidence-based review. Future Frontiers Analytical Report. Sydney: NSW Department of Education. Available online: http://vuir.vu.edu.au/35865/.

LE, C. S. 2016. The human philosophy in the thought of Nguyen Trai. In: Human philosophy in Vietnamese culture. Hanoi: Publisher of Political Theory, pp. 32-44.

LEE, J.E. 2010. Implementation of Lifelong Learning Policies in South Korea: A World Society Perspective. In: Adult Education Research Conference. Available online: http//newprairiepress.org/aerc/2010/papers/45.

LICKONA, T. 2003. The Content of our Character: Ten Essential Virtues. In: The Fourth and the Fifth Rs - Respect and Responsibility, vol. 10, n. 1, pp. 1-3.

MACLEOD, D. 1983. Building character in the American boy: The Boy Scouts, YMCA, and their forerunners, 1870-1920. Madison, WI: The University of Wisconsin Press.

MAI, D. 2019. Ty le nguoi su dung ma tuy tong hop tiep tuc gia tang [The proportion of people using synthetic drugs continues to increase]. Available online: http://thoibaotaichinhvietnam.vn/pages/xa-hoi/2018-06-15/ty-le-nguoi-su-dung-matuy-tong-hop-tiep-tuc-gia-tang-58713.aspx

MAI, P. 2018. 60 trieu nguoi Viet su dụng Facebook [60 Million Vietnamese Use Facebook].. Available online: https://thanhnien.vn/tai-chinh-kinh-doanh/60-trieunguoi-viet-su-dung-facebook-1031621.html

MARDEN LODGE. 2018. Six Pillars of Characters. Marden Lodge Primary School. Available online: http://www.mardenlodge.org/uploads/asset_file/3_0_6-pillarsnotes.pdf 
NGUYEN, Q.H. 2012. Tinh hien dai va doi song ton giao theo quan diem cua Max Weber [Modernity and religious life according to Max Weber]. In: Nghien cuu Ton giao [Religious Studies Review], vol. 6, n. 2, pp. 3-15.

OECD. 2016. Education 2030: Draft discussion paper on the progress of the OECD learning framework 2030. Available online: https://www.oecd.org/education/2030project/contact/E2030_Progress_report_on_the_conceptual_framework_with_visual_ presentation.pdf

PROKHOROV, A.O. - CHERNOV, A.V. - YUSUPOV, M.G. 2017. Dynamics of Mental States' Representations in the Conditions of Experimental Influence. In: Eurasian Journal of Analytical Chemistry, vol. 12, n. 5, A Multidisciplinary Approach to science 5b, pp. 579-590. ISSN 13063057.

ROH, Y.R. 2004. Value education in the Global, Information age in South Korea and Singapore. In: Lee, W.O. - Grossman, D.L. - Kenedy, K.J. - Fairbrother G.P. (eds.). Citizenship Education in Asia and the Pacific: Concepts and Issues. New York: Springer Science and Business Media, pp. 257-274.

SALAS-PILCO, S.Z. 2013. Evolution of the framework for 21st century competencies. In: Knowledge Management \& E-Learning: An International Journal, vol. 5, n. 1, pp.10-24.

SMITH, R. 1968. Viet-Nam and the West. London: Heinemann, 1968.

SONG, T. - USTIN, P.N. - POPOV, L.M. - MUDARISOV, M.M. 2017. The Educational Technology of Ethical Development for Students. In: EURASIA Journal of Mathematics, Science and Technology Education, vol. 13, n. 6, pp. 2095-2110. ISSN 13058215, 13058223.

SVN EDUCATION. 2017. Singapore's Culture - People. Available online: https://svn.edu.vn/van-hoa-con-nguoi-singapo.html

THE PARTNERSHIP FOR 21ST CENTURY SKILLS. 2009. P21 Framework Definitions. Available online: https://www.bullitt.k12.ky.us/userfiles/9/my\%20files/p$21-$

framework2.pdf?id=542784\&fbclid=IwAR1 nut5Hy9JGm9L1nbncFr9tT_enCqN2sP4 W4n5p23Xwe7mX6wxldjryDbM

THEO, B.C.H.Q. 2012. Chien luoc 'giao duc thong minh' cua Han Quoc [Smart Strategy of Korea].. Available online: https://www.nhandan.com.vn/thegioi/item/19359702-.html

THEM, N.T. 2016. Vietnam's value system from tradition to modernity and the way to the future. Hanoi: Culture and Arts Publishing House.

TRAN, N. V. 2002. Nguyen Trai's thought of humanity in "Quan trung tu menh tap." In: Journal of Philosophy, vol. 8, n. 1, pp. 33-39.

TTXVN. 2018. Xay ra hon 25.800 vụ phạm phap hinh su trong 6 thang [More than 25,800 criminal cases within the first 6 months].. Available online : http://tuyengiao.vn/xa-hoi/xay-ra-hon-25-800-vu-pham-phap-hinh-su-trong-6-thang-

113738

UNITED NATIONS DEVELOPMENT PROGRAMME. 2018. Human Development Indicators. UNDP Human Development Reports. Available online: http://hdr.undp.org/en/countries/profiles/VNM

US EMBASSY. 2018. Dai su quan va Tong Lanh su quan Hoa Ky tai Viet Nam (2018). Bao cao tinh hinh buon nguoi nam 2018 [United States Embassy in Vietnam (2018). Human trafficking situation report 2018].. Available online: https://vn.usembassy.gov/vi/tipreport2018/

VALCO, M. 2018. Sekularizacia ako vyzva pre tradicne nabozenstva Europy podla Charlesa Taylora [Deconsecration as a Challenge for Traditional Religions in Europe according to Charles Taylor]. In: Historia Ecclesiastica, vol. IX, n. 1, pp. 173-190.

VIETNAM INSTITUTE OF EDUCATIONAL SCIENCES. 2008. Experiences of some countries in the development of education and training, science and technology associated with building intellectual team. Hanoi: National Political Publishing House. 
VNEXPRESS. 2018. Qua trinh vuon len top dau the gioi cua nen giao duc Han Quoc [The process of rising to the top of the world in Korean education].. VNExpress Portal. Available online: https://vnexpress.net/giao-duc/qua-trinh-vuon-len-top-dau-the-gioicua-nen-giao-duc-han-quoc-3837252.html

WATZ, M. 2011. An historical analysis of character education. In: Journal of Inquiry \& Action in Education, vol. 4, n. 2, pp. 34-53.

XUAN, A. 2016. Nhung vu an "dinh dam" dang chu y 2016 [Notable "cult" cases in 2016]. Available online: https://www.tienphong.vn/phap-luat/nhung-vu-an-dinh-damdang-chu-y-nam-2016-1087434.tpo

Words: 8318

Characters: 57789 (32,10 standard pages)

Dr. Thi Thanh Quy Truong, PhD.

Hanoi Medical University

N01, Ton That Tung Street

Dong Da District, Hanoi City,

Vietnam

truongthanhquyhmu@gmail.com 